\title{
A Critique of Teaching English to Undergraduate Classes with Special Reference to Writing Skill at Aligarh Muslim University
}

\author{
Fatima Sheema \\ Research Scholar, Department of English, Aligarh Muslim University, Aligarh, India \\ E-mail: sheemafatima2002@yahoo.co.in
}

Doi:10.7575/aiac.alls.v.4n.1p.89

URL: http://dx.doi.org/10.7575/aiac.alls.v.4n.1p.89
Received: 05/12/2012

Accepted: 05/01/2013

\begin{abstract}
The present paper attempts to deal with the present scenario of teaching English for Undergraduate students at AMU. The researcher has tried to analyze the needs, materials and the teaching trends as well as learning strategies of the students, at the Undergraduate level. It also illuminates the difference in study skills between groups of student, as per the findings suggested by the questionnaire. For this purpose, two sets of questionnaires were circulated among teachers and students. On the basis of the findings from the data collected, some suggestions regarding changes in classroom pedagogy and materials are recommended. Checking the suitability of the materials in terms of writing skills with regard to students and teachers needs is the main concern.
\end{abstract}

Keywords: Materials, Needs, Teaching trends, Undergraduate level, Writing Skill

\section{Introduction \& Background}

AMU (Aligarh Muslim University), initially established as the Mohammadan Anglo- Oriental (MAO) College in 1875 by Sir Syed Ahmad Khan was an initiative to uplift the socio-economic status of Indian natives, as well as their intellectual advancement, in colonial India. Later, after independence it became a government funded Central University, recognized by UGC (University Grants Commission) where the medium of Instruction, itself is English.

The present paper is a part of ongoing research that deals with Compulsory English, recommended at the two beginning years of graduation (B.A/B.Sc/B.Com $1^{\text {st }}$ and $2^{\text {nd }}$ yr) at AMU. These sheets were produced in-house by a group of teachers from the department of English at AMU. The objective of the course was to equip the learners to proficiently use the basic language skills- LSRW. Herein, the researcher analyzed Writing skill viz. a viz. classroom pedagogy.

\section{Objectives and Research Question}

It was observed that the students often shy away from writing, as L2 writing needs constant efforts, training and practice. This crucial problem led to the observations and findings of the present investigation. The present paper attempts to analyze-

1) Do the needs of learners match with the present syllabus and materials they are studying at present?

2) Differences in study skills.

3) Present materials/ tasks in Compulsory English sheets; and learners' preferences

4) Learning strategies of the learners.

5) Suitability of teaching trends \& present practices.

\section{Literature review}

Teaching Compulsory English at Undergraduate classes in many universities of India is the determined need to train students coming from different vernacular medium, in a single understandable language environment. Most of the literatures of subjects such as history, geography, science etc. are available in English, difficult to be translated in the regional languages, as India is multicultural and multilingual country. With the difficulty for a citizen to learn all the regional languages in order to communicate with the natives of other states inside the country, English was given the status of 'Second' and 'Associate Official Language' after independence. AMU followed the pattern set by UGC after 1960s. In the National Workshop on Syllabus Reform it was recommended that, "English should be taught as a Compulsory subject for a minimum period of two years to B.A, B.Com and B.Sc students."

Nowadays most of the competitive examinations, interviews for jobs, seminars and conferences and other day-to-day events and practices, are held in English throughout the country instead of any vernacular or regional languages. Public notices, websites, newspapers, CV, Matrimonial \& Classifieds (advertisement) and many other varieties of written English are omnipresent in India of today. 
For teachers of writing Barbara Kroll (1993:2) states, 'Barthalomae (1986) sums up how best to view those who teach writing: 'What characterizes writing teachers, I think is not that they have a set of 'methods' for the teaching of writing, but they have a commitment to writing as an intellectual activity and to what that activity can produce in the classroom $(\mathrm{p} .5)^{, 2}$

\section{Materials}

The present Compulsory English Sheets prepared locally in the department of English in the year 2003, contains the writing activities and tasks on the topics given below-

\section{Present(Compulsory English) materials and Items on Writing Skill Course}

B.A/ B.Sc/B.Com $1^{\text {st }}$ yr (Compulsory English Course)-

Unit 2-Note Taking, Summarizing, Precis Writing

Unit-4- Describing Yourself, Friends and relatives, Describing Streets and houses, countries, towns and villages, a day, a journey; Writing Applications; Writing Curriculum Vitae

\section{B.A/B.Sc/B.Com $2^{\text {nd }}$ year (Compulsory English Course)-}

\section{Unit 2-Paragraph writing}

Unit 3-Giving Directions/ Instructions; Writing Processes; Writing Future Plans; Letters of thanks, regret, Condolence, invitation

\section{Participants \& Instrumentation}

The study was conducted among 50 boys and 50 girls (100 in total), a population comprising of students from B.A/B.Sc/B.Com $1^{\text {st }}$ year and $2^{\text {nd }}$ year; and the teachers (around 16 in number out of which 14 responses were returned back) from the Department of English, both males and females.

The main instruments were two sets of questionnaire. The aim of students' questionnaire was to obtain their general background, their learning styles and preferences, their views, ideas and impressions about their English course/ Study materials (Compulsory English Sheets). The second questionnaire was prepared for the teachers. It aimed to know teachers' views about their learners as related to their classroom practices. The return rate of the students' questionnaire was $100 \%$. The return rate of the teachers' questionnaire was $87.50 \%$.

4.3 Data Analysis Method

The response of the subjects was computed by using the statistical program (SPSS) to find both the frequency of occurrence and percentage of the responses.

\section{Results and Discussion}

\subsection{Analysis of Teachers Versus Students Questionnaire}

A total of 14 teachers returned the questionnaire. From the onset of the questionnaire, which deciphered biographical details, it was observed that most of the teachers (12 out of 14 ) $85.71 \%$ were guest faculties, ${ }^{* i}$ one was Assistant Professor (7.14\%) and one Associate Professor (7.14\%). Among those only 7 teachers (50\%) out of 14 possessed specialized ELT training, 2 teachers (14.29\%) were male teachers, while 12 teachers $(85.71 \%)$ were female teachers. From the point of view of nationality, all the 14 teachers (100\%) were Indian Nationals.

100 samples collected from students from five streams (Arts, Social Science, Science, Life- science and Commerce) 40(40\%) revealed the following: native speakers of Urdu 48 (48\%); native speakers of Hindi 11 (11\%); native speakers of other regional Indian languages like Bengali, Kannada etc, 1 student was native of 'Other foreign language'. ii 50 students were from B.A/B.Sc/B.Com $1^{\text {st }}$ year, and 50 were from $2^{\text {nd }}$ year. The questionnaire revealed that these students had their primary, secondary and senior-secondary education from various boards. They demonstrate differences in medium of instruction. (Table 7.1) below, reproduces the gender-wise distribution of the results.

Table7.1 Distribution of Students Responses for Board and Medium of Instruction in terms of Frequency

\begin{tabular}{|l|l|l|l|l|l|l|l|l|l|l|l|l|l|}
\hline Boards & \multicolumn{3}{|c|}{$\begin{array}{l}\text { Male } \\
\text { Students }\end{array}$} & \multicolumn{3}{|c|}{$\begin{array}{l}\text { Female } \\
\text { Student } \\
\text { S }\end{array}$} & \multicolumn{2}{|l|}{$\begin{array}{l}\text { Medium Of } \\
\text { Instruction }\end{array}$} & \multicolumn{3}{|l|}{ Male students } & \multicolumn{2}{|l|}{$\begin{array}{l}\text { Female } \\
\text { Students }\end{array}$} \\
\hline & P & S & SS & P & S & SS & & P & S & SS & P & S & SS \\
\hline AMU & 3 & 4 & 6 & 5 & 6 & 9 & ENGLISH & 18 & 19 & 18 & 38 & 36 & 36 \\
\hline UP & 17 & 18 & 18 & 10 & 11 & 12 & HINDI & 20 & 20 & 19 & 10 & 11 & 11 \\
\hline CBSE & 10 & 8 & 6 & 25 & 24 & 21 & URDU & 8 & 7 & 6 & 1 & 1 & 1 \\
\hline ICSE & 2 & 2 & 1 & 2 & 2 & 1 & BENGALI & 3 & 3 & 3 & 0 & 0 & 0 \\
\hline BIHAR & 1 & 1 & 1 & 0 & 0 & 0 & KASHMIRI & 1 & 0 & 0 & 0 & 0 & 0 \\
\hline KASHMIR & 6 & 6 & 6 & 2 & 2 & 2 & ARABIC & 0 & 1 & 4 & 0 & 0 & 0 \\
\hline BENGAL & 3 & 3 & 3 & 0 & 0 & 0 & PERSIAN & 0 & 0 & 0 & 0 & 0 & 0 \\
\hline $\begin{array}{l}\text { MADARS } \\
\text { A }\end{array}$ & 6 & 6 & 7 & 0 & 0 & 0 & ANY OTHER & 0 & 0 & 0 & 1 & 2 & 2 \\
\hline $\begin{array}{l}\text { ANY } \\
\text { OTHER }\end{array}$ & 2 & 2 & 2 & 6 & 5 & 5 & & & & & & & \\
\hline
\end{tabular}


The data confirms as the majority of the teachers replied that the majority of the students in class were from 'Mixed group'. The frequency of Mixed group was $13(92.86 \%)$, while only one teacher $(7.14 \%)$ responded that the students were from Urban areas. It can be stated that due to mixed groups in classes, teachers have to deal with all the levels, boards, age and background students.

In addition, the information on students' time-period of English study (Table 7.2) answered by the teachers deciphers the results as follows;

Table 7.2 Distribution Of Teachers Responses For Information Regarding Students' Years Of English Study

\begin{tabular}{|l|l|l|l|l|}
\hline & Frequency & Percent & Valid percent & $\begin{array}{l}\text { Cumulative } \\
\text { percent }\end{array}$ \\
\hline Not Sure & 4 & 28.6 & 28.6 & 28.6 \\
\hline 3-5 yrs approx & 2 & 14.3 & 14.3 & 42.9 \\
\hline 6-10 yrs approx & 6 & 42.9 & 42.9 & 85.7 \\
\hline 11-15 yrs approx & 2 & 14.3 & 14.3 & 100.0 \\
\hline Total & 14 & 100.0 & 100.0 & \\
\hline
\end{tabular}

If checked for authenticity from the point of students (male and female students), the results show that 9 boys (18\%) chose the option (1-2 yrs) which is quiet high as compared to 1 girl (2\%), a total of 10 students(10\%). Similarly none of the female students ticked the option (3-5 yrs) while among male students 13 students (26\%) chose this option (3-5 yrs), total of 13 students (13\%). 6 male students and 4 female students opted for the option (6-10 yrs),a total of 10students $(10 \%)$ while 22 male (44\%) students and 45 female $(90 \%)$ students opted for option (11-15 yrs).In other words 67 students (67\%) told that they have studied English for more than 10years. The results can infer various views which could be checked further, it could be that girls have spend more time in learning English than boys. It could also infer that boys are more straightforward in telling the exact detail.

\section{a) Needs and Level of Writing Skill}

Table 7.3 show that with reference to writing skill 1 teacher (7.1\%) reported their students are 'Good', 5 teachers (35.7\%) considered them as 'Satisfactory' and 8 of the 14 teachers $(57.1 \%)$ said that their students proficiency is 'Not Satisfactory'. While for the same question 47 students $(47.0 \%)$ reported themselves to be 'Good', 41 students (41\%) considered them as 'Satisfactory' and 12 students (12.0\%) said that their students proficiency is 'Not Satisfactory'. See table below.

Table 7.3 Distribution Of Teachers Vs Students Opinion For Students Level Of Proficiency In Writing Skill

\begin{tabular}{|l|l|l|l|l|}
\hline & $\begin{array}{l}\text { Frequency } \\
\text { of } \\
\text { responses } \\
\text { by } \\
\text { Teachers }\end{array}$ & $\begin{array}{l}\text { Percent \% } \\
\text { of responses } \\
\text { by Teachers }\end{array}$ & $\begin{array}{l}\text { Frequency of } \\
\text { Responses by } \\
\text { the Students }\end{array}$ & $\begin{array}{l}\text { Percent \% of } \\
\text { Responses by } \\
\text { Students }\end{array}$ \\
\hline Good & 1 & $7.1 \%$ & 47 & $47.0 \%$ \\
\hline Satisfactory & 5 & $35.7 \%$ & 41 & $41.0 \%$ \\
\hline Not Satisfactory & 8 & $57.1 \%$ & 12 & $12.0 \%$ \\
\hline Total & 14 & $100.0 \%$ & 100 & $100 \%$ \\
\hline
\end{tabular}

Figure 7.1 shows 'Why do you think your students need to study English' 9 teachers $(64.3 \%)$ said that the students come in class 'to pass exams', while only 3 students 3\% ticked the same option; 5 teachers $(35.7 \%)$ and 23 students (23\%) chose the option 'For better jobs'; 7 teachers (50\%)and 1 student $(1 \%)$ chose the option 'Interpersonal Communication' and 2 teachers (85.7\%) and 73 students (73\%) informed they studied English 'To improve their English'. In this question they were allowed to tick multiple options. Figure 7.1 depicts the results as follows; 


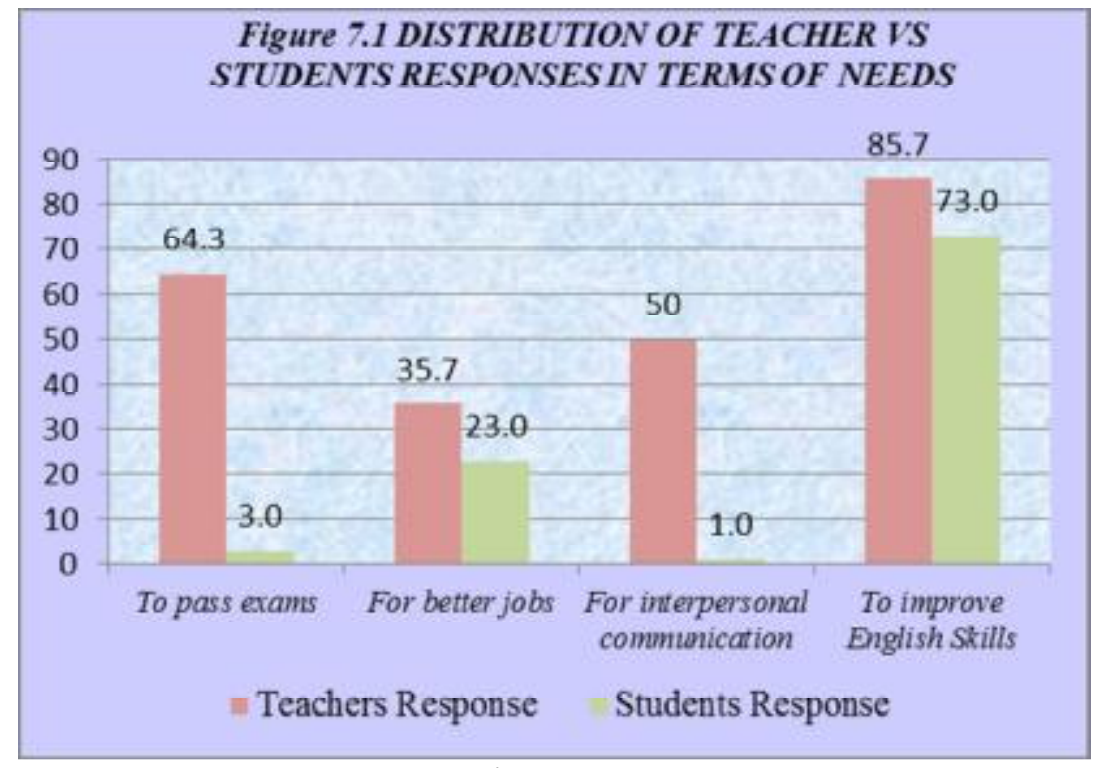

Figure 7.1

The above result depicts a mismatch in the results informing about needs of learners, as opted by learners and as chosen by the teachers. Teaching like this is worthless. It is nothing, but producing mules, without any attention to god-gifted innate capabilities.

\section{b) Study Skill-}

Study Skill is related to skill or expertise of the learner's in managing their study. In response to the answer of the question 'When do you think your students write in English?', see the figure 7.2 below-

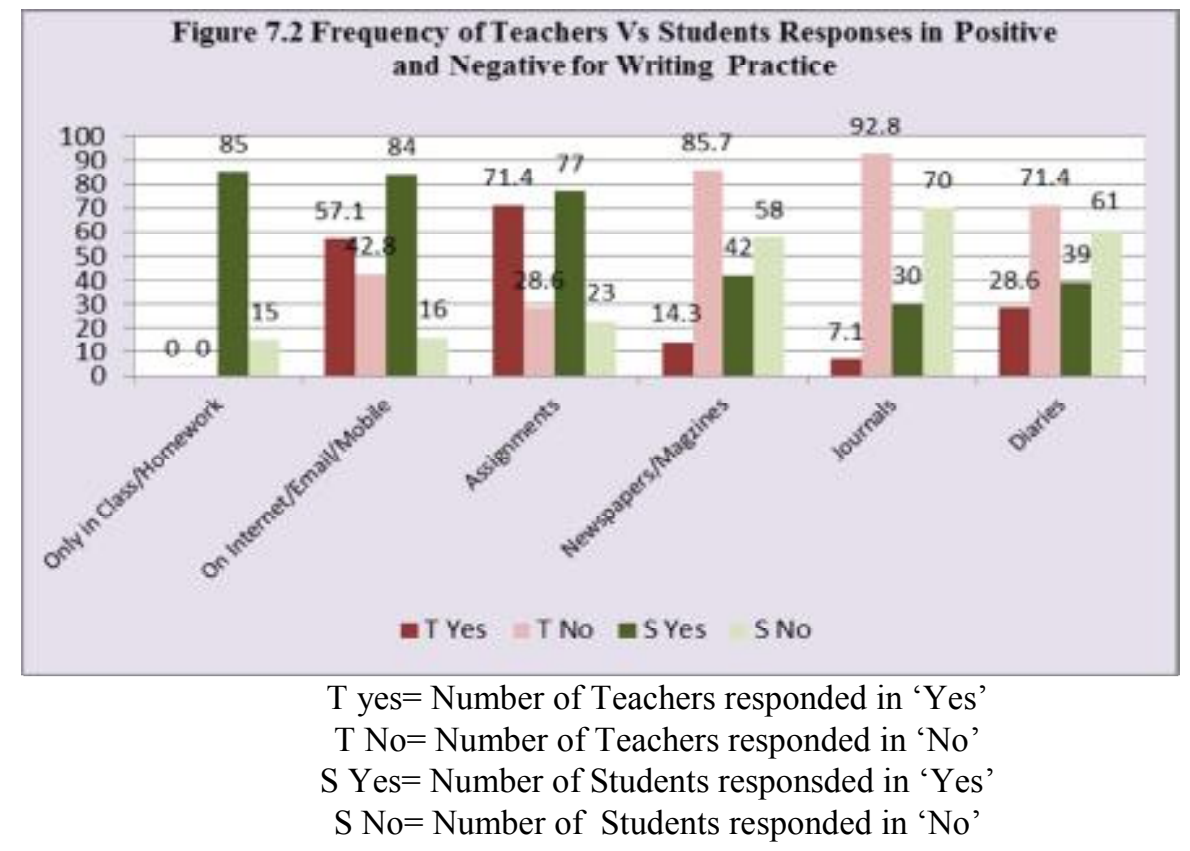

All 14 teachers (100\%) were of view that their students write in English 'Only in class and as homework', 8 teachers (57.1\%) responded that their students often write 'On Internet, Email and Mobile SMS', 10 teachers (71.4\%) told that their students use to write 'Assignments', 2 teachers $(14.3 \%)$ told that their students use to write for 'Newspaper/magazines', 1 teacher(7.1\%) responded that their students use to write in 'Journals' and only 4 teachers (28.6\%) responded that the students prefer writing in 'Diaries'. Whereas for the question 'How often do you write in English?', 85 students (85.0\%) were of view they students write in English 'Only in class and as homework', 84 students (84.0\%) responded that they often write 'On Internet, Email and Mobile SMS', 77 students (77.0\%) told that they use to write 'Assignments', 42 students (42.0\%) told that they use to write for 'Newspaper/magazines', 30 students (30.0\%) responded that they use to write in 'Journals' and only 39 students (39.0\%) responded that the students prefer writing in 'Diaries'. In this question teachers as well as students were free to select multiple options. See Table 7.4 below. 
Table 7.4 Distribution Of Teacher Vs. Students Responses For Materials

Other Than Compulsory Sheets Used In Classroom

\begin{tabular}{|l|l|l|l|l|}
\hline & $\begin{array}{l}\text { Teachers } \\
\text { Response } \\
\text { (Frequency) }\end{array}$ & $\begin{array}{l}\text { Teachers } \\
\text { Response } \\
\text { (percent) }\end{array}$ & $\begin{array}{l}\text { Students } \\
\text { Response } \\
\text { (Frequency) }\end{array}$ & $\begin{array}{l}\text { Students } \\
\text { Response } \\
\text { (Percent) }\end{array}$ \\
\hline $\begin{array}{l}\text { Only in class and as } \\
\text { Homework }\end{array}$ & 14 & $100 \%$ & 85 & $85 \%$ \\
\hline $\begin{array}{l}\text { On Internet Email or Mobile } \\
\text { SMS }\end{array}$ & 8 & $57.1 \%$ & 84 & $84 \%$ \\
\hline Assignment & 10 & $71.4 \%$ & 77 & $77 \%$ \\
\hline Newspaper \& Magazines & 2 & $14.3 \%$ & 42 & $42 \%$ \\
\hline Journals & 1 & $7.1 \%$ & 30 & $30 \%$ \\
\hline Diaries & 4 & $28.6 \%$ & 39 & $39 \%$ \\
\hline
\end{tabular}

In response to the answer of Question 'How do your students prefer to learn English in class?', depicts that only 1 teacher (7.1\%) said that the students prefer to learn 'individually'; 2 teachers $(14.3 \%)$ answered that the students preferred to study in pairs; 5 teachers $(35.7 \%)$ answered that the students wanted to learn in groups; while the majority 6 teachers $(42.9 \%)$ were of view that they wanted 'Tutor-assisted' learning. Whereas, for the same Question 'How do you prefer to learn English?', 46 students(46.0\%) responded 'Individually', 13 students (13\%) answered 'In pairs', 32 students $(32.0 \%$ ) said 'In group' and 9 students ( $9 \%$ ) gave a reply that they prefer 'Tutor/ Teacher assisted' learning.

In response to the answer of Question 'How do your students prefer to read and write?', about 6 teachers (42.9\%) said that the students prefer to learn 'through Books'; only 1 teacher (7.1\%) answered that the students preferred to study by computers; 2 teachers $(14.3 \%)$ answered that the students wanted to learn through authentic materials; while 5 teachers $(35.7 \%)$ were of view that they wanted 'All of the above' options to be included in learning. While for the same question 'How do you prefer to read and write?', about 34 out of $100(34.0 \%)$ students said that the students prefer to learn 'Through Books'; only 1 students (1.0\%) answered that they preferred to study 'Through computers'; 7 students (7\%) answered that they wanted to learn 'through Authentic materials'; while the rest 58 students (58\%) were of view that they wanted through the combination of 'All of the above' options to be included in learning. The first preference is clearly given to 'all of the above option' and second to 'textbook' by both teachers and learners. Teachers' and students' perceived learning style differently. Majority of the teachers emphasized on 'text-book' while majority of students responded for 'authentic materials'.

\section{c) Materials}

The results of question enquiring about the level of Compulsory English Course, look for the results in the table below.

Table 7.5 Distribution of teachers Vs students responses on Level of Course

\begin{tabular}{|l|l|l|l|l|}
\hline & $\begin{array}{l}\text { Frequency } \\
\text { (Teachers } \\
\text { response) }\end{array}$ & $\begin{array}{l}\text { Percent } \\
\text { (Teachers } \\
\text { response) }\end{array}$ & $\begin{array}{l}\text { Frequency } \\
\text { (Students } \\
\text { Response) }\end{array}$ & $\begin{array}{l}\text { Percent } \\
\text { (Students } \\
\text { Response) }\end{array}$ \\
\hline Very Difficult & 0 & $0 \%$ & 1 & $1 \%$ \\
\hline Difficult & 2 & $14.3 \%$ & 28 & $28 \%$ \\
\hline Easy & 11 & $78.6 \%$ & 57 & $57 \%$ \\
\hline Very Easy & 1 & $7.1 \%$ & 14 & $14 \%$ \\
\hline Total & 14 & $100.0 \%$ & 100 & $100.0 \%$ \\
\hline
\end{tabular}

When examined on the basis of responses received by 5 faculties, the results depicted that majority of the students consider the course as 'Difficult'.(Figure7.3)

\section{Figure 7.3 Figure Showing Faculty vise responses received from the students about the level of Course}

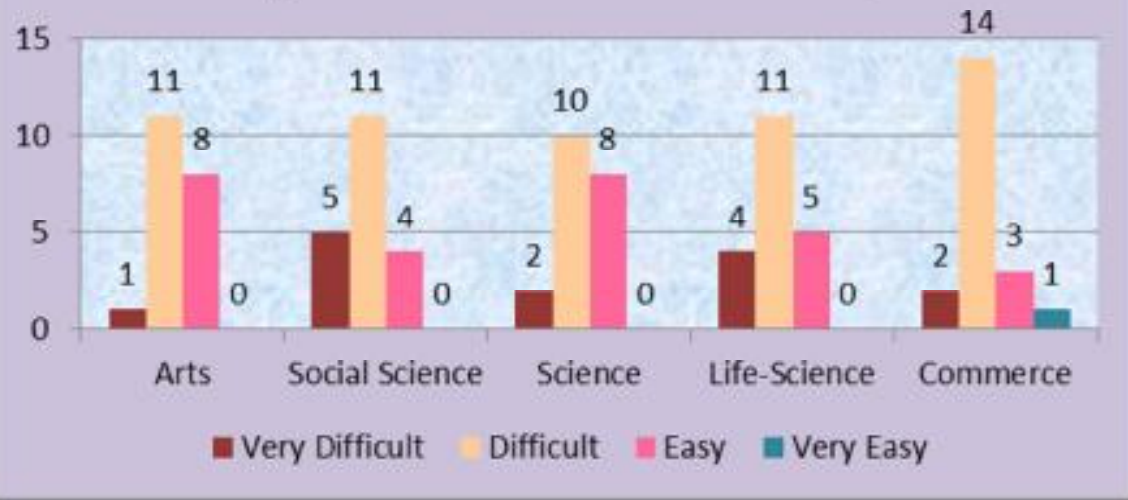

Figure 7.3 
In response to the answer of question 'Is the syllabus suitable to your students needs/requirements?', 2 teachers (14.3\%) replied 'Always', 1 teacher (7.1\%) replied 'Never' and 11 teachers $(78.6 \%)$ replied 'Sometimes'. In response to the answer of same question, the responses of students reflect that 27 students $(27.0 \%)$ replied 'Always', 6 students (6.0\%) replied 'Never' and 67 students (67.0\%) replied 'Sometimes'. These responses are depicted in (Table 7.6) below.

Table 7.6 Distribution Of Teachers Vs. Students Opinion Regarding Suitablity Of Syllabus Items

\begin{tabular}{|l|l|l|l|l|}
\hline & $\begin{array}{l}\text { Frequency } \\
\text { (Teachers' } \\
\text { Responses) }\end{array}$ & $\begin{array}{l}\text { Percent } \\
\text { (Teachers' } \\
\text { Responses) }\end{array}$ & $\begin{array}{l}\text { Frequency } \\
\text { (Students' } \\
\text { Responses) }\end{array}$ & $\begin{array}{l}\text { Percent (Students' } \\
\text { Responses) }\end{array}$ \\
\hline Always & 2 & $14.3 \%$ & 27 & $27.0 \%$ \\
\hline Never & 1 & $7.1 \%$ & 6 & $6.0 \%$ \\
\hline Sometimes & 11 & $78.6 \%$ & 67 & $67.0 \%$ \\
\hline Total & 14 & $100.0 \%$ & 100.0 & $100.0 \%$ \\
\hline
\end{tabular}

In response to the answer of question 'What are the items your students generally like in your Compulsory English Sheets, in Writing Skill? Tick $(\sqrt{ })$ the correct answer, on the basis of your class room experiences.', the teachers put a tick on following options, look at the responses received as depicted in Table $7.7\left(1^{\text {st }} y r\right) \& 7.8\left(2^{\text {nd }} y r\right)$

Table 7.7 Distribution Of Teachers Opinion Regarding Items Students Generally Like In B.A/B.Sc/B.Com $1^{\text {st }}$ Year

\begin{tabular}{|l|l|l|l|l|l|l|l|r|}
\hline & \multicolumn{2}{|l|}{ Frequency } & \multicolumn{2}{l|}{ Percent } & \multicolumn{2}{l|}{ Valid Percent } & \multicolumn{2}{l|}{$\begin{array}{l}\text { Cumulative } \\
\text { Percent }\end{array}$} \\
\hline & Yes & No & Yes & No & Yes & No & Yes & Total \\
\hline $\begin{array}{l}\text { Note Taking \& Note } \\
\text { Making }\end{array}$ & 9 & 5 & 64.3 & 35.7 & 64.3 & 35.7 & 64.3 & 100.0 \\
\hline Summarizing & 5 & 9 & 35.7 & 64.3 & 35.7 & 64.3 & 35.7 & 100.0 \\
\hline Precis Writing & 1 & 13 & 7.1 & 92.9 & 7.1 & 92.9 & 7.1 & 100.0 \\
\hline Writing Descriptions & 11 & 3 & 78.6 & 21.4 & 78.6 & 21.4 & 78.6 & 100.0 \\
\hline
\end{tabular}

Table 7.8 Distribution Of Teachers Opinion Regarding Items Students Generally Like In B.A/B.Sc/B.Com 2nd Year

\begin{tabular}{|l|l|l|l|l|l|l|l|l|}
\hline & \multicolumn{2}{|l|}{ Frequency } & \multicolumn{3}{|l|}{$\begin{array}{l}\text { Pe } \\
\text { rce } \\
\text { nt }\end{array}$} & \multicolumn{2}{|l|}{ Valid Percent } & \multicolumn{2}{l|}{$\begin{array}{l}\text { Cumulative } \\
\text { Percent }\end{array}$} \\
\hline & Yes & No & Yes & No & Yes & No & Yes & Total \\
\hline Paragraph Writing & 9 & 5 & 64.3 & 35.7 & 64.3 & 35.7 & 64.3 & 100.0 \\
\hline $\begin{array}{l}\text { Expressing point of } \\
\text { view }\end{array}$ & 7 & 7 & 50.0 & 50.0 & 50.0 & 50.0 & 50.0 & 100.0 \\
\hline Giving Instructions & 11 & 3 & 78.6 & 21.4 & 78.6 & 21.4 & 78.6 & 100.0 \\
\hline Giving Directions & 7 & 7 & 50.0 & 50.0 & 50.0 & 50.0 & 50.0 & 100.0 \\
\hline Writing a process & 10 & 4 & 71.4 & 28.6 & 71.4 & 28.6 & 71.4 & 100.0 \\
\hline $\begin{array}{l}\text { Generating Dialogues } \\
\text { \& Discussion }\end{array}$ & 9 & 5 & 64.3 & 35.7 & 64.3 & 35.7 & 64.3 & 100.0 \\
\hline Reporting Events & 6 & 8 & 42.9 & 57.1 & 42.9 & 57.1 & 42.9 & 100.0 \\
\hline $\begin{array}{l}\text { Reporting Meeting \& } \\
\text { Speeches }\end{array}$ & 3 & 11 & 21.4 & 78.6 & 21.4 & 78.6 & 21.4 & 100.0 \\
\hline Essay Writing & 4 & 10 & 71.4 & 28.6 & 71.4 & 28.6 & 71.4 & 100.0 \\
\hline
\end{tabular}

The results from the answer of question 'What are the items you like in your Compulsory English Sheets, in Writing Skill? Tick $(\sqrt{ })$ the correct answer.', the responses received as depicted in Table $7.9\left(1^{\text {st }} \mathrm{yr}\right) \& 7.10\left(2^{\text {nd }} \mathrm{yr}\right)$

Table 7.9 Distribution Of Students Opinion Regarding Items They Generally Like In B.A/B.Sc/B.Com 1st Year

\begin{tabular}{|l|l|l|l|l|l|l|l|r|}
\hline & \multicolumn{2}{|l|}{ Frequency } & \multicolumn{2}{l|}{ Percent } & \multicolumn{2}{l|}{ Valid Percent } & \multicolumn{2}{l|}{$\begin{array}{l}\text { Cumulativ } \\
\text { e Percent }\end{array}$} \\
\hline & Yes & No & Yes & No & Yes & No & Yes & Total \\
\hline $\begin{array}{l}\text { Note Taking \& Note } \\
\text { Making }\end{array}$ & 29 & 71 & 29.0 & $\begin{array}{l}71 . \\
0\end{array}$ & 29.0 & 71.0 & 29.0 & 100.0 \\
\hline Summarizing & 29 & 71 & 29.0 & $\begin{array}{l}71 . \\
0\end{array}$ & 29.0 & 71.0 & 29.0 & 100.0 \\
\hline Precis Writing & 16 & 84 & 16.0 & $\begin{array}{l}84 . \\
0\end{array}$ & 16.0 & 84.0 & 16.0 & 100.0 \\
\hline $\begin{array}{l}\text { Writing } \\
\text { Descriptions }\end{array}$ & 34 & 66 & 34.0 & $\begin{array}{l}66.0 \\
0\end{array}$ & 34.0 & 66.0 & 66.0 & 100.0 \\
\hline
\end{tabular}


Table 7.10 Distribution Of Students Opinion Regarding Items They Generally Like In

B.A/B.Sc/B.Com 2nd Year

\begin{tabular}{|l|l|l|l|l|l|l|l|l|}
\hline & \multicolumn{2}{l|}{ Frequency } & \multicolumn{2}{l|}{ Percent } & \multicolumn{2}{l|}{ Valid Percent } & \multicolumn{2}{l|}{$\begin{array}{l}\text { Cumulative } \\
\text { Percent }\end{array}$} \\
\hline & Yes & No & Yes & No & Yes & No & Yes & Total \\
\hline Paragraph Writing & 36 & 64 & 36.0 & 64.0 & 36.0 & 64.0 & 36.0 & 100.0 \\
\hline $\begin{array}{l}\text { Expressing point of } \\
\text { view }\end{array}$ & 16 & 84 & 36.0 & 64.0 & 36.0 & 64.0 & 36.0 & 100.0 \\
\hline Giving Instructions & 13 & 87 & 13.0 & 87.0 & 13.0 & 87.0 & 13.0 & 100.0 \\
\hline Giving Directions & 13 & 87 & 13.0 & 87.0 & 13.0 & 87.0 & 13.0 & 100.0 \\
\hline Writing a process & 7 & 93 & 7.0 & 93.0 & 7.0 & 93.0 & 7.0 & 100.0 \\
\hline $\begin{array}{l}\text { Generating Dialogues } \\
\text { \& Discussion }\end{array}$ & 20 & 80 & 20.0 & 80.0 & 20.0 & 80.0 & 20.0 & 100.0 \\
\hline Reporting Events & 18 & 82 & 18.0 & 82.0 & 18.0 & 82.0 & 18.0 & 100.0 \\
\hline $\begin{array}{l}\text { Reporting Meeting \& } \\
\text { Speeches }\end{array}$ & 18 & 82 & 18.0 & 82.0 & 18.0 & 82.0 & 18.0 & 100.0 \\
\hline Essay Writing & 18 & 82 & 18.0 & 82.0 & 18.0 & 82.0 & 18.0 & 100.0 \\
\hline
\end{tabular}

In response to the answer of question, 'What are the items your students generally don't like studying even if necessary; and are prescribed in Compulsory English Sheets, on Writing Skill? Tick ( $(\sqrt{ })$ the correct answer, on the basis of your class room experiences.', the teachers put a tick on following options. Look at the responses received as depicted in Table $7.11\left(1^{\text {st }} y r\right) \& 7.12\left(2^{\text {nd }} y r\right)$.

Table 7.11 Distribution Of Teachers Opinion Regarding Items Students Generally Don't Like In B.A/B.Sc/B.Com ${ }^{\text {st }}$ Year

\begin{tabular}{|l|l|l|l|l|l|l|l|l|}
\hline & \multicolumn{2}{|l|}{ Frequency } & \multicolumn{2}{l|}{ Percent } & \multicolumn{2}{l|}{$\begin{array}{l}\text { Valid } \\
\text { Percent }\end{array}$} & \multicolumn{2}{l|}{$\begin{array}{l}\text { Cumulative } \\
\text { Percent }\end{array}$} \\
\hline & Yes & No & Yes & No & Yes & No & Yes & Total \\
\hline $\begin{array}{l}\text { Note Taking \& Note } \\
\text { Making }\end{array}$ & 2 & 12 & 14.3 & 85.7 & 14.3 & 85.7 & 14.3 & 100.0 \\
\hline Summarizing & 4 & 10 & 28.6 & 71.4 & 28.6 & 71.4 & 28.6 & 100.0 \\
\hline Precis Writing & 9 & 5 & 64.3 & 35.7 & 64.3 & 35.7 & 64.3 & 100.0 \\
\hline Writing Descriptions & 1 & 13 & 7.1 & 92.9 & 7.1 & 92.9 & 7.1 & 100.0 \\
\hline
\end{tabular}

Table 7.12 Distribution Of Teachers Opinion Regarding Items Students Generally Don't Like In B.A/B.Sc/B.Com 2nd Year

\begin{tabular}{|l|l|l|l|l|l|l|l|l|}
\hline & \multicolumn{3}{l}{ Frequency } & \multicolumn{2}{l}{ Percent } & \multicolumn{2}{l|}{ Valid Percent } & \multicolumn{2}{l|}{$\begin{array}{l}\text { Cumulative } \\
\text { Percent }\end{array}$} \\
\hline & Yes & No & Yes & No & Yes & No & Yes & Total \\
\hline Paragraph Writing & 3 & 11 & 21.4 & 78.6 & 21.4 & 78.6 & 21.4 & 100.0 \\
\hline $\begin{array}{l}\text { Expressing point of } \\
\text { view }\end{array}$ & 3 & 11 & 21.4 & 78.6 & 21.4 & 78.6 & 21.4 & 100.0 \\
\hline Giving Instructions & 1 & 13 & 7.1 & 92.9 & 7.1 & 92.9 & 7.1 & 100.0 \\
\hline Giving Directions & 4 & 10 & 28.6 & 71.4 & 28.6 & 71.4 & 28.6 & 100.0 \\
\hline Writing a process & 1 & 13 & 7.1 & 92.9 & 7.1 & 92.9 & 7.1 & 100.0 \\
\hline $\begin{array}{l}\text { Generating Dialogues \& } \\
\text { Discussion }\end{array}$ & 0 & 14 & 0 & 100.0 & 0 & 100.0 & 0 & 100.0 \\
\hline Reporting Events & 6 & 8 & 42.9 & 57.1 & 42.9 & 57.1 & 42.9 & 100.0 \\
\hline $\begin{array}{l}\text { Reporting Meeting \& } \\
\text { Speeches }\end{array}$ & 6 & 8 & 42.9 & 57.1 & 42.9 & 57.1 & 42.9 & 100.0 \\
\hline Essay Writing & 8 & 6 & 57.1 & 42.9 & 57.1 & 42.9 & 57.1 & 100.0 \\
\hline
\end{tabular}

In response to the answer of question, 'What are the items you don't like in Compulsory English Sheets?' Tick $(\sqrt{ })$ the correct answer.', the students put a tick on following options. Look at the responses received as depicted in Table $7.13\left(1^{\text {st }} \mathrm{yr}\right) \& 7.14\left(2^{\text {nd }} \mathrm{yr}\right)$.

Table 7.13 Distribution Of Students Opinion Regarding Items They Generally Don't Like In B.A/B.Sc/B.Com $1^{\text {st }}$ Year

\begin{tabular}{|l|l|l|l|l|l|l|l|l|}
\hline & \multicolumn{2}{|l|}{ Frequency } & \multicolumn{2}{l|}{ Percent } & \multicolumn{2}{l|}{ Valid Percent } & \multicolumn{2}{l|}{$\begin{array}{l}\text { Cumulative } \\
\text { Percent }\end{array}$} \\
\hline & Yes & No & Yes & No & Yes & No & Yes & Total \\
\hline $\begin{array}{l}\text { Note Taking \& Note } \\
\text { Making }\end{array}$ & 18 & 82 & 18.0 & 82.0 & 18.0 & 82.0 & 18.0 & 100.0 \\
\hline Summarizing & 14 & 86 & 14.0 & 86.0 & 14.0 & 86.0 & 14.0 & 100.0 \\
\hline Precis Writing & 24 & 76 & 24.0 & 76.0 & 24.0 & 76.0 & 24.0 & 100.0 \\
\hline Writing Descriptions & 14 & 86 & 14.0 & 86.0 & 14.0 & 86.0 & 14.0 & 100.0 \\
\hline
\end{tabular}


Table 7.14 Distribution Of Teachers Opinion Regarding Items Students Generally Don't Like In B.A/B.Sc/B.Com 2nd Year

\begin{tabular}{|c|c|c|c|c|c|c|c|c|}
\hline & \multicolumn{2}{|c|}{ Frequency } & \multicolumn{2}{|c|}{ Percent } & \multicolumn{2}{|c|}{$\begin{array}{l}\text { Valid } \\
\text { Percent }\end{array}$} & \multicolumn{2}{|c|}{$\begin{array}{l}\text { Cumulative } \\
\text { Percent }\end{array}$} \\
\hline & Yes & No & Yes & No & Yes & No & Yes & Total \\
\hline Paragraph Writing & 11 & 89 & 11.0 & 89.0 & 11.0 & 89.0 & 11.0 & 100.0 \\
\hline Expressing point of view & 14 & 86 & 14.0 & 86.0 & 14.0 & 86.0 & 14.0 & 100.0 \\
\hline Giving Instructions & 15 & 85 & 15.0 & 85.0 & 15.0 & 85.0 & 15.0 & 100.0 \\
\hline Giving Directions & 14 & 86 & 14.0 & 86.0 & 14.0 & 86.0 & 86.0 & 100.0 \\
\hline Writing a process & 8 & 92 & 8.0 & 92.0 & 8.0 & 92.0 & 8.0 & 100.0 \\
\hline $\begin{array}{l}\text { Generating Dialogues \& } \\
\text { Discussion }\end{array}$ & 11 & 89 & 11.0 & 89.0 & 11.0 & 89.0 & 11.0 & 100.0 \\
\hline Reporting Events & 15 & 85 & 15.0 & 85.0 & 15.0 & 85.0 & 15.0 & 100.0 \\
\hline $\begin{array}{lll}\begin{array}{l}\text { Reporting } \\
\text { Speeches }\end{array} & \text { Meeting \& } \\
\end{array}$ & 12 & 88 & 12.0 & 88.0 & 12.0 & 88.0 & 12.0 & 100.0 \\
\hline Essay Writing & 15 & 85 & 15.0 & 85.0 & 15.0 & 85.0 & 15.0 & 100.0 \\
\hline
\end{tabular}

Table (7.15) shows the answer of 2 questions, respectively.

Table 7.15 Distribution Of Teachers Opinion Regarding Satisfaction Level From The Responses Received, Items Wish To Change \& Use Of Audio/Visual \& Multimedia Resources

\begin{tabular}{|c|c|c|c|c|c|c|}
\hline & \multicolumn{3}{|c|}{ Frequency } & \multicolumn{3}{|c|}{ Percent } \\
\hline & Yes & No & $\begin{array}{l}\text { Can’t } \\
\text { Say }\end{array}$ & Yes & No & Can't Say \\
\hline $\begin{array}{l}\text { Do you wish to change the items } \\
\text { you are teaching in Compulsory } \\
\text { English writing? }\end{array}$ & 7 & 2 & 5 & $50 \%$ & $14.3 \%$ & $35.7 \%$ \\
\hline & Yes & No & ------ & Yes & No & ----- \\
\hline $\begin{array}{l}\text { Do you think teaching assistance } \\
\text { through audio-visual aids/ } \\
\text { multimedia will be useful and } \\
\text { appropriate for your students at } \\
\text { Compulsory English level? }\end{array}$ & 12 & 2 & ------ & $85.7 \%$ & $14.3 \%$ & ------- \\
\hline
\end{tabular}

Table 7.16 also depicts the results as follows-

Table 7.16 Distribution Of Students Opinion Regarding Satisfaction Level From The Responses Received, Items Wish To Change \& Use Of Audio/Visual \& Multimedia Resources

\begin{tabular}{|c|c|c|c|c|c|c|c|}
\hline & & \multicolumn{3}{|c|}{ Frequency } & \multicolumn{3}{|c|}{ Percent } \\
\hline & & Yes & No & Can’t Say & Yes & No & $\begin{array}{l}\text { Can't } \\
\text { Say }\end{array}$ \\
\hline \multirow[t]{2}{*}{$\mathbf{Q}$} & $\begin{array}{l}\text { Do you wish to change the } \\
\text { items you are studying in } \\
\text { Compulsory } \\
\text { writing? }\end{array}$ & 42 & 20 & 38 & $42 \%$ & $20 \%$ & $38 \%$ \\
\hline & & Always & Never & Sometimes & Yes & No & ----- \\
\hline $\mathbf{Q}$ & $\begin{array}{l}\text { Do you think teaching } \\
\text { assistance through audio- } \\
\text { visual aids/ multimedia will } \\
\text { be useful and appropriate } \\
\text { for you at Compulsory } \\
\text { English level? }\end{array}$ & 43 & 5 & 52 & $43 \%$ & $5 \%$ & $52 \%$ \\
\hline
\end{tabular}

The results from the above question emphasizes the fact that the syllabus and the contents need to be revised as soon as possible. 


\section{d) Learning Strategies-}

When analyzed in terms learning strategies the responses to the questionnaire revealed the following. Students data when carefully observed revealed that majority of the students $37 \%$ use 'Internet/email/Social sites/Chat groups; $30 \%$ wrote 'assignments'; 29\% wrote 'articles/poems/stories/essays'; 23\% use to write in 'Vocabulary Criss-Cross' puzzle of newspaper'; $15 \%$ usually write 'Applications/Notices'.

While 9 teachers (64.3\%) said that students write 'Applications/Notices'; 7 teachers $(50.0 \%)$ opted for ' Internet/email/Social sites/Chat groups, 7 teachers (50.0\%) opted for 'Assignments'; 6 teachers (42.9\%) observed there students writing 'Articles/Poems/Stories/Essays' and 2 teachers(14.3\%) opted for 'Vocabulary Criss cross puzzles'.

\section{e) Teaching Trends \& Present practices-}

In response to the answer of Question 'Do you use any other material also, while teaching to improve your students writing skill?' only 5 teachers as in (35.7\%) responded as 'Always' and the rest 9 teachers $(64.3 \%)$ responded 'Sometimes'. While when asked with students, 'Do you refer to any other material also, for improving your English?', only 5 students as in $100(5.0 \%)$ responded as 'No', 37 students (37.0\%) responded as 'Yes' and the rest 58 students $(58.0 \%)$ responded as 'Sometimes'. The results reveal that there is much dependency on textbook (sheets) by both teachers and students.

Some of them, who stated 'Sometimes' opted the name of materials they often use to conern. Among the options newspaper \& magazine, journal, dictionary, TV / internet etc, there were various responses. The teachers responded most for 'Newspaper and magazine' (12 teachers) and 'supplementary material' (13 teachers). While the students views were distributed over for all five options. In this question teachers as well as students were allowed to tick multiple options. The results are shown in Table 7.17 below-

Table 7.17 Distribution Of Teachers Vs Responses For Material Used By Teachers Other Than Compulsory English Sheets To Teach Writing

\begin{tabular}{|c|c|c|c|c|c|c|c|c|c|c|}
\hline & \multicolumn{2}{|c|}{$\begin{array}{l}\text { Frequency } \\
\text { of teachers } \\
\text { responses }\end{array}$} & \multirow[b]{2}{*}{ Total } & \multicolumn{2}{|c|}{$\begin{array}{l}\text { Frequency } \\
\text { of } \\
\text { Students } \\
\text { Responses }\end{array}$} & & \multicolumn{2}{|c|}{$\begin{array}{l}\text { Percent of } \\
\text { teachers } \\
\text { responses }\end{array}$} & \multicolumn{2}{|c|}{$\begin{array}{l}\text { Percent of } \\
\text { students } \\
\text { responses }\end{array}$} \\
\hline & Yes & No & & Yes & No & $\begin{array}{l}\text { Tot } \\
\text { al }\end{array}$ & Yes & No & Yes & No \\
\hline $\begin{array}{l}\text { Newspapers \& } \\
\text { Magazines }\end{array}$ & 12 & 2 & 14 & 73 & 27 & 100 & $85.7 \%$ & $14.3 \%$ & $73 \%$ & $27 \%$ \\
\hline $\begin{array}{l}\text { Dictionary \& } \\
\text { Thesaurus }\end{array}$ & 8 & 6 & 14 & 69 & 31 & 100 & $57.1 \%$ & $42.9 \%$ & $69 \%$ & $31 \%$ \\
\hline Journals \& Articles & 3 & 11 & 14 & 41 & 59 & 100 & $21.4 \%$ & $78.6 \%$ & $41 \%$ & $59 \%$ \\
\hline $\begin{array}{l}\text { Books/Supplementar } \\
\text { y Materials }\end{array}$ & 13 & 1 & 14 & 54 & 46 & 100 & $92.9 \%$ & $7.1 \%$ & $54 \%$ & $46 \%$ \\
\hline TV News \& Internet & 4 & 10 & 14 & 50 & 50 & 100 & $28.6 \%$ & $71.4 \%$ & $50 \%$ & $50 \%$ \\
\hline
\end{tabular}

In response to the answer of Question 'Our teacher gives us his/her own supplementary materials, in addition to the Sheets to make us understand better.', 17 of the students (17.0\%) responded 'Strongly Disagree', 30 of the students (30.0\%) stated 'Disagree', 34 students (34.0\%) 'Agree', and 19 (19.0\%) 'Strongly Agree'. In response to the answer of Question above, none of the teacher $(0 \%)$ responded 'Strongly Disagree', none of the teachers $(0 \%)$ stated 'Disagree', 8 teachers (57.1\%) 'Agree', 5 teacher (35.7\%) 'Strongly Agree' and 1 (7.1\%) was 'Undecided'.

The responses received for question 'How do your students prefer to learn English? Tick $(\sqrt{ })$ the options keeping in consideration your classroom experiences.' 9 teachers (64.3\%) supported view that their students prefer to learn through textbook, 5 (35.7\%) preferred Student-Made material, 6 teachers $(42.9 \%)$ told that their students preferred Teachergiven Supplementary material and 5 teachers (35.7\%) told that they prefer Authentic Materials. In this question teachers were free to select multiple options and they opted for 'yes/No' for every option.

The responses received for question 'How will you prefer to learn English?' 22 students (22.0\%) supported view that they prefer to learn through textbooks, $12(12.0 \%)$ preferred Student-Made material, 17 students $(17 \%)$ told that they preferred Teacher-given Supplementary material and 49 students $(49.0 \%)$ told that they prefer Authentic Materials. In this question too students were free to select multiple options.

For the Question 'Large classes prove a barrier in teaching writing skill and getting feedback', most of the teachers (10 teachers $71.4 \%)$ 'strongly agree' none of them 'Strongly disagree' 1 teacher (7.1\%) 'Disagree', 2 teachers (14.3\%) 'Agree' and 1 (7.1\%) was 'Undecided'.

For the Question 'The teachers' notes are helpful and useful', 6 students $(6 \%)$ responded 'Strongly Disagree', 22 of the students (22.0\%) stated 'Disagree', 54 students (54.0\%) 'Agree' and 18 students (18.0\%) 'Strongly Agree'.

In response to the answer of Question 'I correct my students when they make mistakes while writing in class', none of the teacher $(0 \%)$ responded 'Strongly Disagree', none of the teachers $(0 \%)$ stated 'Disagree', 4 teachers $(28.6 \%)$ 
'Agree', 10 teacher (71.4\%) 'Strongly agree' and none $(0 \%)$ were 'Undecided'. This question aimed to check the approach towards writing skill. This shows that writing accurate master-piece is what most of the teachers still want in their students, instead of paying attention to actual writing process, and constructive feedback.

In response to the Question 'I usually give time to think before my students write', none of the teacher $(0 \%)$ responded 'Strongly Disagree', none (0\%) stated 'Disagree', 7 teachers (50.0\%) 'Agree', 7 teachers (50.0 \%) 'Strongly agree' and none $(0 \%)$ was 'Undecided'. For the same question 2 students (2.0\%) responded 'Strongly Disagree', 7 students (7.0\%) stated 'Disagree', 60 students (60.0\%) 'Agree' and 31 students (31.0\%) 'Strongly agree'.

For the Question 'I explain the rules first, and then ask my students to write', none of the teacher $(0 \%)$ responded 'Strongly Disagree', 1 of the teachers (7.1\%) stated 'Disagree', 4 teachers (28.6\%) 'Agree', 9 (64.3\%) 'Strongly agree' and none $(0 \%)$ was 'Undecided'. For the same Question, 2 students $(2.0 \%)$ responded 'Strongly Disagree', 4 students (4.0\%) stated 'Disagree', 61students (61.0\%) 'Agree' and 33 students (33.0 \%) 'Strongly agree'.

In response to the answer of Question 'I first allow the students to write freely their ideas and then explain the rules', 1 teacher (7.1\%) responded 'Strongly Disagree', 5 teachers (35.7\%) stated 'Disagree', 3 teachers $(21.4 \%)$ 'Agree', 4 teachers (28.6\%) 'Strongly agree' and 1 (7.1\%) was 'Undecided'. For the same question, 2 students $(2.0 \%)$ responded 'Strongly Disagree', 60 students (60.0\%) stated 'Disagree', 27 students (27.0\%) 'Agree' and 11 students (11.0\%) 'Strongly agree'. The above data presents a picture of controlled writing practices, instead of free-writing by the learners.

For the Question 'The students write freely, whatever comes in their mind', none of the teachers $(0 \%)$ responded 'Strongly Disagree', 2 teachers (14.3\%) 'Disagree', 10 teachers (71.4\%) 'Agree', 1 (7.1\%) 'Strongly agree' and 1 (7.1\%) was 'Undecided'. In response to the answer of Question 'I write freely, whatever comes in my mind', 3 students (3.0\%) responded 'Strongly Disagree', 18 students (18.0\%) 'Disagree', 54 students (54.0\%) 'Agree' and 25 (25.0\%) 'Strongly agree'.

For the Question 'My students begin writing by brainstorming \& mind-mapping', none of the teachers $(0 \%)$ responded 'Strongly Disagree', 1 teacher (7.1\%) stated 'Disagree', 11 of the teachers $(78.6 \%)$ 'Agree', none ( $0 \%)$ 'Strongly agree' and $2(14.3 \%)$ were 'Undecided'. In response to the same Question 'I begin writing by brainstorming \& mindmapping', 4 students (4.0\%) responded 'Strongly Disagree', 32 students (32.0\%) stated 'Disagree', 51 students (51.0\%) 'Agree' and 13 (13.0\%) 'Strongly agree'.

For the Question 'The time allotted for writing skill activities is sufficient to train my students', none of the teachers $(0 \%)$ responded 'Strongly Disagree', 9 teachers $(64.3 \%)$ 'Disagree', 2 teachers (14.3\%) 'Agree', 1 (7.1\%) 'Strongly agree' and $2(14.3 \%)$ were 'Undecided'. In response to the same question, 7 students $(7.0 \%)$ responded 'Strongly Disagree', 29 students (29.0\%) stated 'Disagree', 55 students (55.0\%) 'Agree' and 9 students (9.0\%) 'Strongly agree'.

For the Question 'My students feel more comfortable to write, without my help and guidance as a teacher', 2 teachers (14.3\%) 'Strongly Disagree', 7 teachers $(50.0 \%)$ stated 'Disagree', 2 teachers $(14.3 \%)$ 'Agree', none of them $(0 \%)$ 'Strongly agree' and $3(21.4 \%)$ were 'Undecided'. In response to the same, 9 students (9.0\%) 'Strongly Disagree', 47 students (47.0\%) 'Disagree', 26 of the students (26.0\%) 'Agree' and 18 of them (18.0\%) 'Strongly agree'.

For the Question 'Students mostly use dictionary while writing', 2 teachers (14.3\%) 'Strongly Disagree', 7 teachers $(50.0 \%)$ 'Disagree', 3 teachers (21.4\%) 'Agree', none of them (0\%) 'Strongly agree' and 2 (14.3\%) were 'Undecided'. In response to the same question, 5 students (5.0\%) 'Strongly Disagree', 32 students (32.0\%) 'Disagree', 47 students $(47.0 \%)$ 'Agree', and 16 of them (16.0\%) 'Strongly agree'.

For the Question 'Students usually take help from their friends, while writing', none of the teachers ( $0 \%)$ 'Strongly Disagree', 2 teachers (14.3\%) 'Disagree', 11 teachers (78.6\%) 'Agree', 1 of them (7.1\%) 'Strongly agree' and none $(0 \%)$ were 'Undecided'. For the same question 11 students (11.0\%) 'Strongly Disagree', 35 students (35.0\%) stated 'Disagree', 44 students (44\%) 'Agree', 10 of them (10\%) 'Strongly agree'.

\section{Problem areas}

1) There is a mismatch in needs as stated by students and indicated by teachers.

2) Textbooks (Compulsory English Sheets) claim that process approach is followed, but in actual classroom practices, it might not be so.

3) Some of the classrooms are 'Instructions and practice oriented' rather than 'Activity and opportunity oriented'.

4) Students with all five streams (Arts, Science, Social Science, Arts, Commerce) are studying the same syllabus and materials, and they have a common exam/ summative assessment (annual exam).

5) Slow learners and weaker students have more difficulty in coping up with the materials and course. Students are not streamed in classes according to their level and aptitude.

6) Large Classes acts as barrier in teaching. Teachers are dealing with large number of students in classes, sometimes even more than 100 per class.

7) Peer-correction is not practiced.

8) The amount of writing the students usually do, as per responses 'Only in class and as homework' depicts that learners lack writing practice. They write out of pressure and not self-motivation.

9) Task and activities are well-prepared but there are no graphics or pictures in the whole Sheets. Low-level learners generally look for pictures or illustrations for interpretation. 
10) Teachers had to teach the prescribed syllabus in a limited time-span.

11) Faulty and hectic assessment procedures, which don't judge learning and teaching in an effective way.

\section{Conclusion and recommendations}

From the findings of the results of the questionnaire it can be suggested that-

1) There is a need for teachers training. Teachers' manual could be another cheaper option that can be supplemented with the core materials.

2) Re-evaluation of syllabus and materials.

3) Streaming of students in classes according to their level. For this purpose help from diagnostic test, aptitude test and personality test before the commencement of classes are recommended.

4) Extra classes and Bridge courses for weak students and students from Madarsa background.

5) Assessment techniques should also be revised, and manual assessment should be replaced by computerized assessment.

6) Materials and method in classroom should encourage self-motivation and not enforcement. Teachers attitude should not be a hindrance in learning. Authentic materials should be properly used.

7) Learners could be given decision-making authority to choose their own syllabus and materials, with some sort of parental and administrative control. Teachers should also get flexibility and opportunity in selecting syllabus items to be introduced to their learners, produce their own materials and assessing their learners in their own new ways.

8) Need for co-ordination among learners, teachers, administration and government; and a need of an interface where every learner can get a chance to share and discuss, criticize in a positive manner, suggest changes, and explore new things; teachers can be free to share opinions, ask for suggestions, and trained in the best possible manner, administrators should check the syllabus, materials and classroom practices frequently and set predetermined objectives for defining the systematized educational environment; and government should be an asset and not a hindrance in teaching-learning. Help from Computers and idea of blended learning could be a better solution. A website by the department on which the teachers and students are free to post every teachinglearning activity might be useful. This must contain pages where teachers can post their course plans, announcements, assignments, lessons, results etc. and students have discussion boards, procedure of checking the wall-posts, online assignments.

9) Weak students should be encouraged for free writing by the teachers instead of guided and controlled writing.

10) There is a need for further research in other skills suggesting changes which can keep up with the changing times.

\section{References}

University Grants Commision (UGC) 1977:01

Kroll,B (1990). Second Language Writing. Cambridge University Press: Cambridge

Tomlinson, B. (1998).Materials Development in Language Teaching. Cambridge University Press: Cambridge

Mukundan, J., Nimehchisalem, V., \& Hajimohammadi, R. (2011). Developing an English language textbook evaluation checklist: A focus group study. International Journal of Humanities and Social Science, 1, 100-105.

Notes:

${ }^{\mathrm{i}}$ Guest faculties are on temporary and contract basis.

ii Other foreign languages includes foreign language other than English and Arabic, like Persian, Irani, etc 